\title{
Farmers' Ability to Pay for Irrigation Water in the Jordan Valley
}

\author{
Mohammad Tabieh*, Emad Al-Karablieh, Amer Salman, Hussein Al-Qudah, \\ Ahmad Al-Rimawi, Tala Qtaishat \\ Department of Agricultural Economic and Agribusiness, Faculty of Agriculture, The University of Jordan, \\ Amman, Jordan \\ Email: *m.tabieh@ju.edu.jo
}

Received 19 August 2015; accepted 27 September 2015; published 30 September 2015

Copyright (C) 2015 by authors and Scientific Research Publishing Inc.

This work is licensed under the Creative Commons Attribution International License (CC BY). http://creativecommons.org/licenses/by/4.0/

(c) (i) Open Access

\begin{abstract}
This study aims to analyze the famers' ability to pay for irrigation water in Jordan Valley to investigate the farmer capacity to cope with increasing the water tariff. The residual imputation approach was used based on the enterprise budget for crops cultivated in different geographical locations in Jordan Valley. This methodology deducts the contribution of non-water production inputs, annualized capital cost and fixed costs from the gross output and attributes the remaining value to water. The resulting water value is an indication of the economic efficiency of water and a proxy for the maximum farmer's ability to pay for water. The result shows that cucumber has the highest ability to pay (JD $2.26 \mathrm{~m}^{-3}$ ); the percentage of water cost to total cost is $1.1 \%$. This low percent does not encourage farmers to save water. The weighted average for maximum farmers' ability to pay for irrigation water in Jordan valley is estimated at JD $0.76 \mathrm{~m}^{-3}$. The result shows the farmer's ability to pay for water used in plastic house is JD $1.34 \mathrm{~m}^{-3}$ compared to JD $0.62 \mathrm{~m}^{-3}$ for open field. The estimated value of desalinated brackish water is JD $0.59 \mathrm{~m}^{-3}$ while the average desalination cost is JD $0.28 \mathrm{~m}^{-3}$. Therefore, the current practice of installing Reverse Osmosis units to irrigate high value cash crops by some farmers is economically rational, since water value is twice the desalination cost of one cubic meter. If farmers have to pay the cost of $0 \& M$, they need to pay at least JD $0.065 \mathrm{~m}^{-3}$. Increasing the water prices could encourage more efficient water use, shifts to higher value crops, adoption of plastic houses, and encourage desalination of brackish water.
\end{abstract}

\section{Keywords}

Water Tariff, Water Value, Water Cost, Residual Imputation Approach, Water Resources

\footnotetext{
${ }^{*}$ Corresponding author.
}

How to cite this paper: Tabieh, M., Al-Karablieh, E., Salman, A., Al-Qudah, H., Al-Rimawi, A. and Qtaishat, T. (2015) Farmers' Ability to Pay for Irrigation Water in the Jordan Valley. Journal of Water Resource and Protection, 7, 1157-1173. 


\section{Introduction}

In a country facing such a significant imbalance between limited supplies and ever-growing demand, the government must grapple with very difficult policy decisions and trade-offs in order to determine the best ways to allocate water across sectors. This is especially true for the agricultural and industrial sectors which consume significant portions of the national water supply and are central to the Jordanian economy. A critical component of improved resources management is a more informed policy setting process. Jordan's water sector is struggling to keep up with rapid population growth and economic growth. Jordan is one of the most water scarce countries in the world [1], with very limited quantities of renewable water and high costs for providing water to people and businesses. Sustaining public projects for irrigating agricultural activities requires expenditures in a form of capital investment, operations and maintenance, and periodic rehabilitation. Government has historically been the primary sources for financing these projects, but farmer beneficiaries are increasingly expected to contribute substantially toward recovering full costs. Estimates of farmers' ability to pay (ATP), or repayment capacity, for part or all of the costs of irrigation water supply facilities are useful in deciding on how much of these costs farmers can and should pay for irrigation water. Willingness to pay depends at once on individuals' level of income and their perception of risk: the greater a person's aversion to risk, the more he or she will be willing to pay. An individual's ability to pay is the maximum amount that he or she is capable of paying; it is therefore linked to income. Ability to pay is always greater than or equal to willingness to pay, even for persons with a strong aversion to risk. In a context of poverty, however, the levels of ability to pay and willingness to pay are both very low and tend to be indistinguishable from one another [2]. The average tariff billed per cubic meter of water billed to irrigation in 2010 range from JD 0.008 to $0.016 \mathrm{~m}^{-3}$, with an average of JD $0.012 \mathrm{~m}^{-3}$. Based on billed water volume, the average operation and maintenances cost per cubic meter billed are about JD 0.12 per $\mathrm{m}^{3}\left(0.17\right.$ US\$ $\left.\mathrm{m}^{-3}\right)$ in the three years (2008-2010), while the average revenue of irrigation water in Jordan Valley (JV) is only JD 0.03 per $\mathrm{m}^{3}$. Jordan Valley Authority (JVA) is not able to cover its basic operating costs; its revenues fall far short. The decline of JVA's capacity to pay for its operating expenditures has been especially pronounced since 2008. The operating margin is highly negative and shows that currently the total revenues including pumping revenues which were not charged to Water Authority of Jordan (WAJ) do not even cover staff costs. The operating cost coverage ratio is less than 30 percent for all purposes of water use and only $10 \%$ of irrigation water [3]. Water in Jordan Valley is charged according to the principle of price discrimination and quota system. In 2004, the JVA revised the quotas system for better supply of water and crop water requirements [4]. The new quotas correspond to 360, 765 and $1255 \mathrm{~m}^{3} / \mathrm{du}$ for vegetables, citrus and bananas, respectively, i.e., a cut by about 20 to 25 percent. At a regional scale, this generated total freshwater savings in the northern and middle directorates of approximately $20 \mathrm{mcm}$. The water saved was subsequently reallocated to domestic use in Amman with about $53 \mathrm{mcm}$ in 2010. In sight the value of water is essential to support policy decision making about 1) investments in water supply system, 2) investments in the water distribution system and the irrigation system, 3) efficient allocation of water with competing sectors, 4) setting water pricing and tariffs, 5) setting cost recovery (O\&M and capital recovery) mechanisms, and 6) determining the socio-economic impacts of water management decisions [1]. However, the decision-makers are thus torn between pressures to meet water authorities' demands for expansion and maintenance, and public pressure to restrict water prices, particularly for poor people. Pressures from donor communities to adopt full water cost recovery aggravate the situation. Water pricing is the most important measure in establishing effective demand management to use water efficiently and sustainably. Appropriate and adequate operation and maintenance of water systems are necessary to enable them to meet the current and future requirements for distributing water. Decision makers often lack information on unit value of water to agricultural revenue in different agricultural activities and their relative economic contributions to the local and regional economies. As a result, they cannot adequately assess potential trade-offs amongst different agricultural users under different management schemes. The question that this paper seeks to explore is how much a farmer would pay for water and at what price farmers plan to cultivate the area they have under irrigation. Regardless of the reason for reforming water policies, knowledge of the value of water is essential for efficient allocations of water and when crafting policies to compare the variable impacts of water reform within and across sectors of the economy. However, a major difficulty that policy makers and water resources managers face is over accurately determining net economic value of irrigation water due to a number of economic, political, and physical complexities. Economic gains (or net values of irrigation water) of some agricultural activities are much higher than others but these activities may require major initial investment and take 
years before economic gains are achieved. Also, the issue of large sunk costs in on-farm infrastructure impacts on the net economic value of irrigation water. Such investment costs have not been incorporated in the previous ISSP water valuation study [5].

\section{Materials and Methods}

\subsection{Review of Literature}

The idea of water as an economic good is simple. Water has a value to users who are able to pay for it. Like other goods, consumers will use water as long as the benefit derived from the use of an additional cubic meter exceed the costs so incurred, i.e. until the marginal value product of water equals its price. The capacity to pay for water depends directly on farmers' incomes, especially from crop enterprises. According to the economic theory, a farmer will be able and willing to apply water to the crops as long as it generates more income than its per unit cost. If the marginal income from a crop by application of an additional unit of irrigation water is less than the water charge for that crop, the farmer is not able to pay for water. The net income criterion generally serves as a good approximation of farmers' ability to pay for water charges. Net farm income, as a measure to assess the average paying capacity of the water users [6]. Establishing economic value for water is considered to be one of the most discussed and debated issues related to economic efficiency of water use and its allocation [7] [8]. Young stated that: "water valuation presents the economic analyst with a wide range of challenging issues and problems, because water values tend to be quite site-specific, spatial, and temporal, and each case confronts its own unique issues and typically requires its own original valuation" [9]. Effective measurement of water values demands skill and rigor in application of all the tools of the applied economist's trade. These tools include data collection, statistical analysis, optimization models, and research reporting. However, researchers have employed many methods for assessing the value of irrigation water. These methods have been classified into two major groups, namely "inductive techniques" and "deductive techniques" [9]. The inductive techniques (based on observation in market) for valuing irrigation water differ mainly according to the type and source of data and the form of statistical model, if any, used to estimate the productivity relationship. Most commonly used inductive techniques include: (a) direct observations on water entitlement markets, (b) land value method by imputing value of water via land and implementing valuation from land market data, (c) hedonic property (or revealed preference) value method; and (d) econometric valuation of irrigation water from primary and secondary data including stated preference techniques [1] [5]. Ability to pay (ATP) and willingness to pay (WTP) are economic concepts, which aims to determine the amount of money a consumer is able or willing to pay for the supply of additional unit of goods and services and it is water in our case. The consumers' ATP and WTP are becoming increasingly popular and are one of the standard approaches that are used by market researchers and economists to place a value on goods or services for which no market-based pricing mechanism exists [10]. Literature suggests that two approaches are being used to analyses the consumers' ATP/WTP. The direct approach, involves taking a survey through a structured questionnaire of consumers' ATP/WTP specified prices for hypothetical services, also referred as contingent valuation method (CVM). The direct approach used in CVM has been to directly ask survey respondents to state their exact maximum ATP/WTP for the particular use or non-use value of the water. The ATP/WTP is defined as the amount that can be taken away from person's income while keeping his utility constant [11]. The CVM still have serious methodological and theoretical shortcomings when used to assess ATP/WTP for non-market based goods and services, such as format bias, embedding effect, ordering problem, starting bid effects, strategic bias, information bias, non response bias, payment vehicle, free rider problem, warm glow effect [12]-[14]. However, CVM is still useful tool for water resource management in developing countries. The price of water in a water market should reflect water's economic value. Because water is usually supplied by public agencies who price water at its average financial delivery cost rather than its value to producers, water is rarely priced at its marginal economic value [9]. Water can be valued from a supply (i.e. depending on the cost of water provision) or demand perspective (value added due to water use in productive activities), resulting in a supply curve or a demand curve. When water is an input to a production process (an "intermediate good"), such as in irrigated agriculture or in industrial use, water demand is derived from the demand for the final output and from water's role in producing this output; thus it is a derived demand function. In this case, water demand is a function of the price of water and the price of the final product produced. Estimating water's economic value is equivalent to isolating the marginal contribution of water to the total output value [9] [15]. In general, the most scientifically accepted methods are those based on actual market behavior 
and information [16] [17]. In the case of Jordan, since farmers in the Jordan Valley are paying for water-a neglected portion of production costs; it is difficult to establish a relationship between price and demand from actual behavior to generate demand functions. Moreover, the fact that water is provided by the government with heavy subsidies, strategic biases or simply the belief among farmers that water is a free gift from God [18], could probably lead to erroneous estimations of water values when using direct methods such as contingent valuation [12]. Therefore, following Lange [19] and Speelman [20], the Residual Imputation Method (RIM) was used in this study. Although this method clearly has its shortcomings, it was considered the most suitable technique to estimate water values for the studied irrigation schemes [21].

\subsection{Objectives of the Study}

This study aims to analyze the famers' ability to pay for irrigation water in Jordan Valley from farmers' perspective that takes into account the full economic costs of production using RIM approach. The previous water valuation study conducted in Jordan provide a short-run disaggregated water value for fruits, vegetable, and field crops at the regional and country level. They take into consideration the water value added-according to different agro-climatological zones and the type of water used in the production process such as groundwater versus surface or blended waste water with surface water [22]. The major distinction in this study is in the estimation of water value through farmers' ability to pay for water in the long run where all fixed costs are variable costs in the long runs. The growing water scarcity causes increasing pressure on farmers to allocate water more efficiently. The JVA does not cover the O\&M cost. The average tariff billed per cubic meter of water billed to irrigation in 2010 is JD 0.012 per $\mathrm{m}^{3}$. Based on billed water volume, the average operation and maintenances

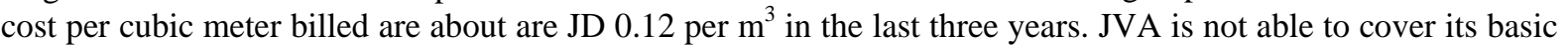
operating costs; its revenues fall far short. The operating cost coverage ratio is less than 30 percent for all purpose of water use and only 10 percent of irrigation water [3]. Therefore, to formulate a new water policy, water subsidies currently received by farmers will gradually decrease and become negative, i.e. in the near future; farmers will have to pay for the water they use. This paper will try to estimate the economic value of water in agriculture by producing well-differentiated estimates of Farmers' Ability to Pay (FAP) for irrigation water in Jordan Valley.

\subsection{Background to Economy and Agriculture in Jordan Valley}

The agriculture sector is a major consumer of water, and the returns to water from crop production tend to be low in comparison to other sectors. The horticulture is becoming the main source of agriculture GDP. The horticulture sector can be divided into highland and Jordan Valley. Around 61 percent of Jordanian agriculture GDP is generated from Jordan Valley. About 19 percent and 17 percent of agricultural GDP is generated from MJV and NJV, respectively [23]. The irrigated agriculture is mainly based on surface and marginal water resources in the Jordan valley, where the highlands the irrigation is based on groundwater resources. The importance of the agricultural sector in MJV stems from the fact that it is the major source fruits and vegetables during winter season (35\% of value added in winter vegetables), and also one of the sources of hard currencies originated from exports. One can use a rough estimate of value added of irrigation water by dividing the total value added (agriculture GDP) in each geographical location in JV by water consumed in each location. The NJV yielded the highest gross water value added with JD 1.4 per cubic meter [24]. The Jordan Rift Valley (JRV) is a low-lying strip that extends along Jordan's west border from northern Jordan near Lake Taiberia at an elevation of about $212 \mathrm{~m}$ b.s.l. to southern Jordan near Aqaba. The part of the JRV covered by this paper is that extends from northern Jordan to near the Dead Sea where elevation drops to about $420 \mathrm{~m}$ b.s.l., the lowest point on earth. The study area experiences a sharp gradient in rainfall from north to south. Average annual rainfall in the Northern Jordan Valley is about $377 \mathrm{~mm}$ and $77 \mathrm{~mm}$ in southern Shouneh [25]. The prevailing subtropical climate in the JRV and fertile soil allows for year around cultivation especially vegetables in winter. About $70 \%$ of Jordan's production of fruit and vegetables is from the Jordan valley which makes the valley Jordan's food basket. Total irrigable area in the Jordan Valley is about 363,000 dunum. The main water demand in the Jordan Valley is agricultural demand. Irrigation water demand in the Jordan Valley is distributed from north to south among five demand zones which are the Northern Jordan Valley (NJV), the Middle Jordan Valley (MJV), the Southern Jordan Valley (SJV), the extension project in the Southern Dead Sea (Safi) and recently Wadi Araba (Table 1). Irrigation water demand in the Jordan Valley is estimated at about 320 million cubic meter $(\mathrm{mcm})$ per year based 
Table 1. Distribution of farm units and irrigated areas by source of irrigation water in Jordan Valley.

\begin{tabular}{|c|c|c|c|c|c|c|}
\hline Zone & $\begin{array}{l}\text { Stage } \\
\text { office }\end{array}$ & $\begin{array}{l}\text { Development area } \\
\text { (DA) }\end{array}$ & $\begin{array}{l}\text { No. of farm } \\
\text { units }\end{array}$ & $\begin{array}{l}\text { Irrigated area } \\
\text { (du) }\end{array}$ & Water source & Project name \\
\hline \multirow{5}{*}{$\begin{array}{c}\text { Northern } \\
\text { Jordan Valley } \\
\text { (NJV), North } \\
\text { Directorate }\end{array}$} & 1 & $1,2,6,7$ & 365 & 12,892 & KAC, Yarmouk & $\begin{array}{l}\text { North Ghor Conversion } \\
\text { Project }\end{array}$ \\
\hline & 2 & 11,12 & 365 & 13,886 & KAC, Yarmouk & $\begin{array}{l}\text { North Ghor Conversion } \\
\text { Project }\end{array}$ \\
\hline & 2 & $12,13,14,15,16$ & 584 & 20,477 & $\begin{array}{l}\text { KAC, Yarmouk, KTR } \\
\text { (ZCIII) }\end{array}$ & $\begin{array}{l}\text { North Ghor Conversion } \\
\text { Project }\end{array}$ \\
\hline & 7 & $3,4,5$ & 379 & 12,525 & KAC, Wadi Arab & Wadi Arab Project \\
\hline & 7 & $\begin{array}{c}8,9,10,33,34 \\
35,36,37,38,39\end{array}$ & 756 & 28,791 & $\begin{array}{l}\text { KAC, Dam, Zeglab Dam, } \\
\text { Al-Gorom Dam }\end{array}$ & North East Ghor Project \\
\hline \multirow{5}{*}{$\begin{array}{c}\text { Middle Jordan } \\
\text { Valley (MJV), } \\
\text { Deir Alla } \\
\text { Directorate }\end{array}$} & Sub Total & & 2449 & 88,571 & & \\
\hline & 3 & $18,19,20,21$ & 498 & 20,339 & KAC, KTR (ZCIII) & $\begin{array}{l}\text { North Ghor Conversion } \\
\text { Project }\end{array}$ \\
\hline & 4 & 23 & 683 & 25,623 & KTR (ZCII), KAC & $\begin{array}{l}\text { Middle Ghor Conversion } \\
\text { Project }\end{array}$ \\
\hline & 5 & $24,25,30,54$ & 696 & 26,582 & KTR (ZCII), KAC & $\begin{array}{l}\text { Middle Ghor Conversion } \\
\text { Project/ZorSheshaa }\end{array}$ \\
\hline & 8 & 22,53 & 383 & 14,212 & KTR (ZCII), KAC & $\begin{array}{l}\text { Middle Ghor Conversion } \\
\text { Project/Abo Zegan }\end{array}$ \\
\hline \multirow{6}{*}{$\begin{array}{c}\text { Southern Jordan } \\
\text { Valley (SJV), } \\
\text { Karameh } \\
\text { Directorate }\end{array}$} & Sub Total & & 2260 & 86,756 & & \\
\hline & 8 & 29 & 337 & 11,454 & KTR (ZCI) & Zarka Triangle Project \\
\hline & 6 & $26,27,28$ & 1,026 & 39,794 & KTR, KAC & 18 km extension Project \\
\hline & 9 & $49,50,51,52$ & 1,382 & 56,600 & KTR, KAC, Shueib & 14.5 km Project \\
\hline & 10 & 31,32 & 458 & 15,580 & Kafrien Dam, Mujeb & Hisban-Kafrain Project \\
\hline & Sub-Total & & 3203 & 123,429 & & \\
\hline \multirow{3}{*}{$\begin{array}{l}\text { Safi, Southern } \\
\text { Ghor Directorate }\end{array}$} & 11 & $\begin{array}{l}40,41,42,43,44 \\
\quad 45,46,47,48\end{array}$ & 1552 & 47,730 & $\begin{array}{l}\text { Ibn Hammad, \& Al-Karak, } \\
\text { Mujeb Dam }\end{array}$ & $\begin{array}{l}\text { Southern Ghors Project } \\
\text { /stage I }\end{array}$ \\
\hline & 12 & $55,56,57$ & 326 & 10,217 & $\begin{array}{l}\text { WadiHisan, Fifa, Tanur } \\
\text { dam }\end{array}$ & $\begin{array}{l}\text { Southern Ghors Project } \\
\text { /stage II }\end{array}$ \\
\hline & Sub-Total & & 1,878 & 57,947 & & \\
\hline Wadi Araba & 13 & 58 & 325 & 6,500 & Ground Water Wells & $\begin{array}{l}\text { New Wadi Araba Irrigation } \\
\text { Project }\end{array}$ \\
\hline Grand Total & & & 10,115 & 363,203 & & \\
\hline
\end{tabular}

Source: MWI, 2013.

on crop water requirements (or roughly $360 \mathrm{mcm}$ by the assumption of $1000 \mathrm{~m}^{3}$ water requirements per dunums annually). Domestic demand in the Jordan Valley is minor compared to the total agricultural demand which is satisfied from groundwater sources. The JVA is a government organization in charge of the economic and social development of the valley and retains the responsibility for operation and maintenance of the irrigation system including water distribution. The JVA has a directorate for operation and maintenance stationed in the valley. It employs over 1500 workers, 1362 employees were in the Water Division, of which about 250 take care for the operations [26]. There are three "regional" JVA field offices which calculate the water flow to each farm unit. A control central office monitors the calculated consumption for the entire valley, compares it to the water inflows from the various sources and calculates the un-accounted for water. The cultivation of citrus and banana is al- 
lowed only through license from JVA. The Jordan Valley irrigation scheme consists of 58 development areas that each depend on one common source of water, either surface or blended surface with treated wastewater or groundwater (Table 1). The water source is either one of the 28 pumping stations along the KAC or a direct inflow from a side wadi or a dam. Water is conveyed from the source (KAC or side wadis) to farmers' fields through a pressure pipe network and distributed to each farm unit (ca. 35 dunum) by an end user outlet, called a farm turnout assembly. All sources of water (surface water from Yarmouk river, side wadis and dams, Lake Tiberias, the main conveyor, KAC, its pump stations, the distribution networks and farm turnout assemblies and drinking water off-take from the KAC to Amman) are centrally monitored but are decentralized in operation [27]. These features make the Jordan Valley irrigation system almost unique, being a dual irrigation and municipal water supply system which is very difficult to compare with irrigation systems in other countries.

The total cultivated areas in JV in 2011 is about 363 thousand dunums, of which 311 thousand dunums is fully irrigated. The vast majority of irrigated agricultural production is in the form of fresh fruits and vegetables. As indicated in Table 2, about 60 percent of the irrigated areas in Jordan are allocated to vegetables. About 45 percent of total production and irrigated area of vegetables in Jordan are in Jordan Valley. Irrigated areas of fruit trees in JV occupy 23 percent of total irrigated areas of fruit trees and produce about 51 percent of total fruit trees production.

Water resources in the Jordan Valley consist of ground water, surface water, and treated wastewater from KTD. The safe yield of the Jordan Valley basin is estimated at $20 \mathrm{mcm}$ and the safe yield of the Jordan Valley side wadis basin is estimated at $31 \mathrm{mcm}$ [28]. Other sources in the Jordan Valley are Yarmouk River, Taiberia Lake, and Mukheba wells. The amount received from Yarmouk River varies significantly from year to year which depends on rainfall and on the upstream use by Syria. For example Yarmouk River flow at Adasiya near the inlet to KAC for the year 2004 was about $69 \mathrm{mcm}$ which dropped to about $12.6 \mathrm{mcm}$ for the year 2011 [26]. Flow from Taiberia Lake is governed by the Peace treaty which is about $50 \mathrm{mcm}$ per year. The total water inflows into Jordan Valley fluctuated from year to year depends on rainfall precipitation. The total water inflows estimated in year 2011 with $211 \mathrm{mcm}$. The flow of Mukheiba wells in 2011 was about $25.5 \mathrm{mcm}$. Water from Yarmouk River, Taiberia Lake and Mukheiba wells flows at the upstream of King Abdulla Canal, which is the main transfer system in the Valley and extends from the northern Jordan Valley about $110 \mathrm{~km}$ to the south and ends a short distance before the Dead Sea. In addition, several side wadis distributed along the valley flow from east to west, the base flow of which is estimated at about $19.6 \mathrm{mcm}$ [26]. These side wadis flow to the Jordan River, however, some water from these side wadis is used for private irrigation in the upstream area. In addition, four small dams exist on these wadis, the storage capacity of which is about $30 \mathrm{mcm}$. Al-Karameh dam with a storage capacity of about $52 \mathrm{mcm}$ is the largest dam in the JRV; unfortunately its water is saline and can't be used for irrigation. A desalination plant was constructed to desalinate about $12 \mathrm{mcm}$ per year to be used for domestic purposes but due to some technical problems, mainly high salinity, it's not in operation. Furthermore, brackish springs and tube well are existed in the Jordan Valley, some of which are desalinated and used for irrigation by private farmers. To compensate for the loss of Yarmouk river water, the Jordan Valley Authority extended the existing Zarqa Carrier II (which conveys water from the Zarqa river downstream of the King Talal Dam (KTD) to the King Abdullah Canal (KAC) to the North Ghor irrigation area. The new pipeline, called Zarqa Carrier III, enables another 4000 ha to be irrigated with water from KTD. In 2010 about 2 mcm were delivered from KTD to Northern areas and increased to about $10.3 \mathrm{mcm}$ in 2011 from a total water use of $37 \mathrm{mcm}$

Table 2. Irrigated areas under tree crops, field crops, and vegetables in 2012.

\begin{tabular}{ccccccc}
\hline Crops & $\begin{array}{c}\text { Irrigated area in } \\
\text { Jordan (dunums) }\end{array}$ & $\begin{array}{c}\text { Irrigated area in } \\
\text { JV (dunums) }\end{array}$ & $\begin{array}{c}\text { Percentage of } \\
\text { irrigated area in JV } \\
\text { to total irrigated } \\
\text { areas }\end{array}$ & $\begin{array}{c}\text { Production of } \\
\text { irrigated area in } \\
\text { Jordan (ton) }\end{array}$ & $\begin{array}{c}\text { Production of } \\
\text { irrigated area in } \\
\text { Jordan Valley } \\
\text { (ton) }\end{array}$ & $\begin{array}{c}\text { Percentage of JV } \\
\text { production to total } \\
\text { production }\end{array}$ \\
\hline Tree crops & 469,751 & 107,672 & $23 \%$ & 337,992 & 171,356 & $51 \%$ \\
Field crops & 87,549 & 20,283 & $23 \%$ & 168,268 & 30,570 & $18 \%$ \\
Vegetables & 407,195 & 183,627 & $45 \%$ & $1,915,149$ & 876,058 & $46 \%$ \\
Total & 964,495 & 311,581 & $32 \%$ & $2,421,409$ & $1,077,983$ & $45 \%$ \\
\hline
\end{tabular}

Source: DOS, 2012. 
[26]. The carrier is intended originally to be used in dry periods only as an emergency supply if fresh surface water resources in the KAC run out, alternating fresh water supply and supply from KTD. The Disi fossil water carrier is completed in August 2013 and it is starting to provide additional between $75-80 \mathrm{mcm}$ of fresh water for municipal purpose in Amman-Zarka basin. Consequently an additional $50-60 \mathrm{mcm}$ of treated wastewater are available in the KTD. However, the total water use for irrigation purpose in Jordan valley estimated with an average of $133 \mathrm{mcm}$. An average of about $57 \mathrm{mcm}$ of water are lost and unaccounted for, either for system inefficiency, lost, evaporations and illegal uses. This transition comes with considerable problems. The water taken from KTD has a salinity of around $1400 \mathrm{mg} /$, which negatively affects yields, especially citrus, when compared with irrigation from fresh water resources. Also, because of increasing availability of treated wastewater resources, the use of treated wastewater in the northern part of the Jordan Valley will be considered in the near future to reduce the stress on freshwater resources for rural and urban areas in the Northern governorates. It is therefore expedient to prepare farmers for the permanent use of treated wastewater for irrigation of citrus and other crops. Experiences from the southern part of the Jordan Valley cannot be extended without further action research to the northern part, as the northern part receives higher rainfall, different soil type and different cropping pattern, a major factor to be taken into account when adapting to the different quality of irrigation water.It is important to note that fresh water upstream of the KAC at Deir Alla is pumped to Zai Water Treatment Plant which provides drinking water to west Amman, pumping from KAC to Zai WTP for the years between 2010 and 2011 about $53.5 \mathrm{mcm}$. Furthermore, groundwater resources in the Jordan Valley are also used to satisfy part of the domestic demand in Irbid governorate. Treated wastewater generated in Amman and Zarqa is a main water resource in the Jordan Valley. Wastewater generated in Amman and Zarqa is treated at As-Samra WWTP and discharged to Zarqa River which ends in KTD. As-Samra WWTP flow to Zarqa River grew from about 61 MCM for the year 2007 to about 84 MCM for the year 2010. Water from KTD is released to KAC where it gets mixed with fresh water there and used for unrestricted irrigation in the Middle and southern Jordan Valley. The facility is acknowledged for being the first project in Jordan to be built under a build, operate and transfer (BOT) basis and the first to receive a grant from USAID. With a peak flow of 840,000 cubic meters each day, the facility treats an average flow of 267,000 cubic meters of wastewater on a daily basis, serving a population of about 2.2 million living in the Greater Amman and Zarqa areas. An expansion of the facility began in 2012 and is expected to be completed by 2016. It will increase the plant's average treatment capacity to 133 million cubic meters each year. The estimated treated wastewater use in 2010 is estimated with $100 \mathrm{mcm}$. About $55 \mathrm{mcm}$ was used in Jordan Valley [29]. Beyond all this, the fact that Jordan, provide irrigation water in JV to farmers at subsidized prices implies that the governments involved consider water in the hands of farmers to have a greater value than the farmer's own willingness to pay. Such a view may be because of social effects-the desirability of social order and to avoid social unrest, and because of political considerations, as well as to keep the stability of food prices. The success of structural reforms in the water sector depends on sustained, determined political commitment to implement them, on the support of supplementary reforms in regulatory regimes, realistic and efficient tariff structure and on a clear policy on subsidy and its mechanisms to provide quality service to the poor. It is to be noted that effective regulation is a necessary but not a sufficient condition.

\subsection{Methodology}

This study focuses on the use of water as an intermediate good, used as an input in the production of other goods and services. When used as an intermediate good, the value of water must be assessed from the producers' point of view. The conceptual valuation framework for the welfare benefits of increases or decreases in water use is provided by the producers' demand for inputs, including water. Therefore, the deductive techniques include residual imputation approach are commonly used to derive real prices of irrigation water. A residual method for valuing irrigation water is a special case of the well-known process of performing farm budget or cost and return analysis. This method subtracts the incremental value added by all production inputs except the irrigation water from the value of total output. The method identifies the incremental contribution of each input to the value of the total output and is the most widely used methodology for valuing irrigation water [9]. All costs of production except water are subtracted from the value of production and the remaining (or residual) value provides an estimate of the value of water in irrigation. The resulting value sometimes termed "quasi-rent" [30] and can be assumed to be the net value of irrigation water [31]. The residual imputation method is most suitable where the residual contributes the largest fraction of the value of output. This method requires the subtraction of the eco- 
nomic cost of all the other production inputs except water from the sales revenue. The difference becomes the value of water in the production of commodity. The application of the principle of ability to pay is based on profitability of irrigated farms as the basis for water pricing. In estimating the ability of irrigators to pay for water, typically we uses farm budget studies for the area in question to determine the net productivity of irrigation water for various crops and various type of land. Once the crop pattern and the size of the average farm are estimated, the total net productivity of water is computed after subtracting all other costs (operational and fixed costs), including normal profits under the guise of a "farm family living allowance". Therefore, the use of water in a production process can be determined using the residual imputation approach. The residual value represents the maximum amount the producer would be willing to pay for water and still cover input costs [32]. If only variable input costs are subtracted, then a short-run measure of the value of water is derived. If the costs of all nonwater inputs are subtracted (including a normal rate of return on capital), then a long-run value is obtained. Three methods can be used derive water values in agricultural sector, these are:

1. Water values based on the Gross Value Added (GVA): The GVA represents the difference between the gross output of the farm minus the intermediate consumption. The resulting water productivity allows for determining the farmers supply curve of the agricultural products in the short run. The farmer is willing to pay that price of water to avoid losses in the short run and to recover the variable cost. All the fixed cost does not recover and lost.

2. Water values based on the Net Value added (NVA): NVA is the value of output less the values of both intermediate consumption and annualized fixed capital. NVA is obtained by deducting consumption of fixed capital (or depreciation charges plus opportunity cost of invested capital) from GVA, NVA. Therefore equals gross wages, pre-tax profits net of depreciation, and indirect taxes less subsidies

3. Water values based on the Net Profitability (NP): The net profitability is the measure of the surplus or profit accruing from production after deducting all costs (direct and indirect) and thus a proxy for total pre-tax profit income. The resulting water value is an indication about the economic efficiency of water consumption and a proxy for farmer's ability to pay for water. If the farmers changed this value for water they reach an equilibrium in the long run and normal profit. This implies that the sales revenue exactly equals the sum of all inputs used. In this case, there is no reward to risk and uncertainties in doing business. However, the farmers receives normal rate of return on invested capital.

However, any costs incurred by a firm may be classed into two groups: fixed costs and variable costs. Fixed costs, which occur only in the short run, are incurred by the business at any level of output, including zero output. These may include equipment maintenance, rent, wages of employees whose numbers cannot be increased or decreased in the short run, and general upkeep. Variable costs change with the level of output, increasing as more products is generated. Materials consumed during production often have the largest impact on this category, which also includes the wages of employees who can be hired and laid off in the span of time (long run or short run) under consideration. Fixed costs and variable costs combined together equal total costs. Therefore, in this attempt we takes into account the sunk costs in the form of asset fixity such as amortization of capital investments, opportunities costs of invested capital, amortization of capital land, opportunities costs of family labors [33]. The management will attempt to maximize profits by employing just the right amount of each factor of production subject to a predefined budget constraint. At a much more general level, profit maximization may be viewed as an unconstrained or constrained optimization problem where the decision variable is the firm's level of output. The marginal product of water $\left(M P_{w}\right)$ is the change in total output given a unit change in the amount of water used. The marginal revenue product of water $\left(M R_{w}\right)$ is the change in the firm's total revenue resulting from a unit change in the amount of water used. The marginal revenue product is the marginal product of water times the selling price of the product $\left(P_{y}\right)$, i.e., $M R_{w}=P_{y} \cdot M P_{w}$. The total cost of water is the price rate times the total amount of water used. The marginal resource cost of water $\left(M R C_{w}\right)$ is the change in total water cost resulting from a unit change in the number of units of water used. If the price rate $\left(P_{w}\right)$ is constant, then the price rate is equal to the marginal cost of water. A profit-maximizing firm that operates in perfectly-competitive output and input markets will employ additional units of water up to the point where the marginal revenue product of water is equal to the marginal water cost, i.e., $P_{y} \cdot M P_{w}=P_{w}$. The problem confronting the decision-maker is to choose an output level that will maximize profit. Define profit as the difference between total revenue and total cost, both of which are functions of output, i.e., $\pi(Q)=T R(Q)-T C(Q)$. The objective is to maximize this unconstrained objective function with respect to output. The first-order and second-order conditions for a maximum are $\mathrm{d} p / \mathrm{d} Q=0$ and $\mathrm{d}^{2} p / \mathrm{dQ}^{2}<0$, respectively. The profit maximizing condition is to produce 
at an output level at which $M R=M C$. Although profit maximization is the most commonly assumed organizational objective, firms that are not owner-operated, or firms that operate in an imperfectly competitive environment often adopt an organizational strategy of total revenue maximization. The first-order and second-order conditions are $\mathrm{d} T R / \mathrm{d} Q=0$ and $\mathrm{d}^{2} T R / \mathrm{d} Q^{2}<0$, respectively. Assuming that firms are price takers in resource markets (the price of water is fixed); because price and output are always positive, it can be easily demonstrated that the output level that maximizes total revenue will always be greater than the output level that maximizes total profit. This is because of the law of diminishing marginal product guarantees that the rate of increase in marginal cost is greater than the rate of increase in marginal revenue [34]. To obtain the profit maximizing output quantity $(y)$, we start by recognizing that profit is equal to total revenue $T R(y)$ minus total cost $T C(y)$. The profitmaximizing output is the one at which this difference reaches its maximum. Therefore, a firm's profit is its revenue minus its cost. If the price $p_{y}$ at which the firm can sell its output is not significantly affected by the size of its output, it is reasonable to model the firm as taking the price as given. In this case, for a single product, its total revenue is $T R(y)=p_{y} \cdot y$, where $y$ is its output. Thus the firm's profit function is

$$
\pi(y)=T R(y)-T C(y)=P_{y} \cdot y-T C(y)
$$

where TC is either the firm's long run cost function, the firm chooses its output y to maximize its profit $\pi(y)$, taking price as given. The net profit $\pi\left(y_{j}\right)$ in term of (JD/dunum) equals the gross revenue less all annualized capital cost $\left(C C_{j}\right)$ and other fixed costs $\left(F C_{j}\right)$, which form total fixed costs $\left(T F C_{j}\right)$, all variable costs $\left(V C_{j}\right)$ including water charges $\left(Q_{w} \cdot P_{w}\right)$. Assume the producer objective is to maximize profits of single output as a function on multiple inputs $Y=f\left(X_{i}\right)$, leaving one single input, water in our case water $\left(Q_{w}\right)$ separately. Then the profit equation is:

$$
\pi=P_{y} \cdot Y-\sum_{i=1}^{n} P x_{i} \cdot X_{i}+T F C+P_{w} \cdot Q_{w}
$$

To find the conditions for optimal profits, take the first derivative of $\pi$ with respect to water and set that equal to zero:

$$
\frac{\mathrm{d} \pi}{\mathrm{d} Q_{w}}=P y \cdot \frac{\mathrm{d} f(Y)}{\mathrm{d} Q_{w}}-P_{w}=0
$$

The $\mathrm{d} f(Y) / \mathrm{d} Q_{w}$ is the marginal products of water, $P y \cdot \mathrm{d} f(Y) / \mathrm{d} Q_{w}$ is the is the value of the marginal product (VMP) of water, where the value of marginal product is defined as output price multiplied by the marginal physical productivity of the input [34]. If all the inputs, including water, are exchanged in a competitive market and employed in the production process, the value of water of the last cubic meter used should equal its price. Rearrange equation [17] then

$$
P_{w} \cdot Q_{w}=P_{y} \cdot Y-\left(\sum_{i=1}^{n} P x_{i} \cdot X_{i}+T F C+\pi\right)
$$

When economic profit is equal to zero; this occurs when the difference between total revenue and total cost (explicit and implicit costs) equals zero. Normal profit is different than accounting profit because opportunity cost is taken into consideration. Normal profit is the minimum level of profit needed for a firm to remain competitive in the market. Profit in economics, is the return on conducting business and risk, also called earnings, minus the costs of maintaining land, labor, and capital. Thus, normal profit is the profit that could be earned in another activity elsewhere. It is the profit that could be earned in an alternative venture.

Residual valuation thus assumes that if all markets are competitive, except the one for water, the total value of production $\left(P_{y} \cdot Y\right)$ equals exactly the opportunity costs of all the inputs. It is assumed that the opportunity costs of non-water inputs are given by their market prices (or their estimated shadow prices). The residual, obtained by subtracting the non-water input costs from total annual crop revenue equals the gross margin (water related contribution equal gross margin minus the water costs) and can be interpreted as the maximum amount the farmer who could pay for water and still cover costs of production. It represents the at-site value of water.

$$
P_{w}=\left[P_{y} \cdot Y-\left(\sum_{i=1}^{n} P_{i} X_{i}+T F C\right)\right] / Q_{w}
$$

In this study the water values were derived by three methods: these methods are: 
1. Water values based on the gross value added,

$$
P_{w}=\left[P_{y} \cdot Y-\left(\sum_{i=1}^{n} P_{i} X_{i}\right)\right] / Q_{w} .
$$

2. Water values based on the net value added,

$$
P_{w}=\left[P_{y} \cdot Y-\left(\sum_{i=1}^{n} P_{i} X_{i}+C C\right)\right] / Q_{w}
$$

3. Water values based on the net profitability,

$$
P_{w}=\left[P_{y} \cdot Y-\left(\sum_{i=1}^{n} P_{i} X_{i}+T F C\right)\right] / Q_{w}
$$

The derived monetary amount derived from the last equation where net profit divided by the total quantity of water used on the crop production, determines the marginal value for water, corresponding to the irrigator's maximum ability to pay per unit of water for that crop [35]-[37]. However, the assumptions of the RIM are not overly restrictive, but care is required to assure that conditions of production under study are reasonable approximations of the conceptual model. The main issues can be divided into two types: 1) those relating to the specification of the production unction and 2) those relating to the market and policy environment (i.e., the pricing of outputs and non-residual inputs), [9]-[19]. The residual value is assumed to equal the returns to water and represents the maximum amount the producer would be willing and able to pay for water and still cover input costs [32]. If only variable input costs are subtracted, then a short-run measure of the value of water is derived. If the costs of all non-water inputs are subtracted (including a normal rate of return on capital), then a long-run value is obtained.

\subsection{Data Collection}

Questionnaires were used to collect data for the period 2011-2012. These data encompass production (ton), cultivated area (du), yield (kg/du) by season in 4 districts in Jordan Valley. The estimation of the value of water for agriculture is performed on a per crop basis. The main field crops, vegetables and fruit trees in Jordan Valley are selected. In total 160 farmers were interviewed, spread over 4 irrigation schemes. The interviews gathered information on irrigation system, farm activities, quantities and costs of inputs used in production, quantities and value of output, quantity of water consumed and irrigation practices. Expert knowledge of the extension staff was used as a verification method to farmers' answers. This was particularly helpful for the estimation of water use and prices of inputs and outputs. After constructing an enterprise budget, a group of progressive producers is interviewed by the author in the targeted areas. The author and a farm management specialist work together to modify and develop a consensus estimate of enterprise costs and returns. It is fully realized by those involved in this process that the resulting enterprise budget does not represent any particular farm. The individual farmer must be modified it to fit his situation. However, the resulting budget is a reasonable estimate for each geographical location in the targeted area. Therefore, the ability to pay is expected to vary by location in JV, by time (winter vs. summer), and by water quality (surface, groundwater and blended water) and by individual based on his situation and endowments. The detailed collected data from farmers' field allows us to assess water values that are differentiated according to crop type, geographic area, seasons and water quality. Enterprise budgets are estimated for most of the fruits, field crops, and vegetable crops grown in Jordan Valley in different agro-ecological zones. The returns and costs were calculated on per dunum basis. The estimated enterprise budgets are based on the best and most accurate estimates on returns and costs available in 2012 for 226 observations. The net irrigation water applied by farmers is used to measure the value of irrigation water (which is subtracted later from calculation), fertilizers (trace elements, organic and compound or chemical fertilizer), pesticides and herbicides., containers and threads, plastic mulch used in vegetable production with drip irrigation, and under plastic houses, plastic sheet and cover used in plastic tunnels crop enterprises, fuel and electricity. The costs of hired machinery and seasonal hired labor expressed in hours, which includes planting, spraying, tillage, land preparation, rearing, and crop harvesting, have been calculated for all these operations. The gross margins were calculated without including irrigation water cost in the total variable cost. The fixed costs include expenses of all non-varying inputs required for the production process. The annual depreciation expenses for the crops are varying according to production systems. Total costs are the sum of both cost components, variable and fixed costs. 
Net returns of the selected enterprises were obtained through deducting the total costs from the gross returns for each crop. In calculating labor costs for the enterprise budgets, operator and family labor are valued at their opportunity cost of being hired out to a neighboring farmer. The shadow price was calculated based on discussions with farmers and extension personnel and on the data on wage labor in the dataset. For land that is owned, the opportunity cost that is included in the budget is the net rental return that the producer would receive if the land was rented out rather than being used by the producer [38] [39].

\section{Results and Discussion}

The farmers' ability to pay will be presented separately with classified according to geographical location, crop type, water quality cropping season and production and irrigation technology. The residual water value is assumed to equal the returns to water and represents the maximum amount the producer would be willing to pay for water and still cover input costs. The approach is also extremely sensitive to small variations in assumptions concerning the nature of the production function or prices. The water values based on gross value added and net value added will be presented but will not be discussed, since it represents the water values in the short run. The farmers will be able to pay such value in order to avoid crop losses.

\subsection{Farmers' Ability to Pay by Location}

Farmer's ability to pay in term of water profitability vary from region to region depending on economic activity, climate zones, production season, soils and water qualities, in addition to many other factors. Table 3 shows the average of water value and water profitability values in different regions. The highest water values are found in MJV with JD $1.59 \mathrm{~m}^{-3}$. However, water profitability was found in MJV has the highest value of about JD 0.93 $\mathrm{m}^{-3}$, Safi, and northern JV are similar with the value of about JD $0.79 \mathrm{~m}^{-3}$. SJV is the lowest with about JD 0.62 $\mathrm{m}^{-3}$. This might be because of the dominance of banana fruits in SJV, which require a high amount of water compared with MJV where vegetables are the dominant cropping pattern. The percent of water cost to total costs was the lowest value is found in MJV with $1.24 \%$. The water costs ranges between $1.24 \%$ to $2.35 \%$ with an average of $1.88 \%$. The results shows that water cost represent a neglected portion in the variable costs and total costs. This lowest portion does not encourage farmers to take a serious measure to conserve water and encourage a rational use of water. Farmers in highland areas, where water cost exceeds JD $0.7 \mathrm{~m}^{-3}$, are taken serious measures to avoid any loss in the irrigation network and practicing deficit irrigation.

\subsection{Farmers' Ability to Pay by Crop Type}

The field crops include wheat, barley, alfalfa, maize and garlic. The water profitability in field crops is among the lowest in Jordan valley. However, the weighted average for ability to pay in field crop production is JD $0.134 \mathrm{~m}^{-3}$. It is worth mentioning that field crop gown in JV for crop rotation purposes The cost of water represent a significant portion of total costs in field crop. The costs of water represent about $6 \%$ of the total variables cost and about $4.5 \%$ in the total costs as shown in Table 4. The average water profitability for the fruit trees is JD $0.53 \mathrm{~m}^{-3}$. The average water value in Banana is JD $0.48 \mathrm{~m}^{-3}$ it ranged from JD $0.652 \mathrm{~m}^{-3}$ in the SJV to a lowest of JD $0.22 \mathrm{~m}^{-3}$ in NJV. Looking to the net profit to one cubic meter, it was found it is about JD 0.48 $\mathrm{m}^{-3}$ for banana crops. Therefore, it is economically rational for banana producers to install RO units to irrigate bananas, since the cost of desalination of one cubic meter is about the half of net profit from one cubic meter.

Table 3. Farmers' ability to pay and cost of water relative to total costs by location in JV.

\begin{tabular}{cccccc}
\hline Location & $\begin{array}{c}\text { Water gross value } \\
\text { added }\left(\mathrm{JD} \mathrm{m}^{-3}\right)\end{array}$ & $\begin{array}{c}\text { Water net value added } \\
\left(\mathrm{JD} \mathrm{m}^{-3}\right)\end{array}$ & $\begin{array}{c}\text { Water net profitability } \\
(\mathrm{FAP})\left(\mathrm{JD} \mathrm{m}^{-3}\right)\end{array}$ & $\begin{array}{c}\text { Percent cost of water } \\
\text { to intermediate costs }\end{array}$ & $\begin{array}{c}\text { Percent cost of water } \\
\text { to total costs }\end{array}$ \\
\hline NJV & 1.327 & 1.157 & 0.791 & $2.59 \%$ & $1.85 \%$ \\
MJV & 1.591 & 1.333 & 0.931 & $1.81 \%$ & $1.24 \%$ \\
SJV & 1.341 & 1.143 & 0.622 & $2.95 \%$ & $2.35 \%$ \\
Safi & 1.279 & 1.156 & 0.794 & $2.18 \%$ & $1.65 \%$ \\
Average & 1.365 & 1.179 & 0.763 & $2.54 \%$ & $1.88 \%$ \\
\hline
\end{tabular}


Table 4. Farmers' ability to pay and cost of water relative to total costs by crop type in JV.

\begin{tabular}{cccccc}
\hline Crop Type & $\begin{array}{c}\text { Water gross value } \\
\text { added }\left(\mathrm{JD} \mathrm{m}^{-3}\right)\end{array}$ & $\begin{array}{c}\text { Water net value added Water net profitability } \\
\left(\mathrm{JD} \mathrm{m}^{-3}\right)\end{array}$ & $\begin{array}{c}\text { Percent cost of water } \\
\text { (FAP) }\left(\mathrm{JD} \mathrm{m}^{-3}\right)\end{array}$ & $\begin{array}{c}\text { Percent cost of water } \\
\text { to total costs }\end{array}$ \\
\hline Winter Veg. & 1.559 & 1.325 & 0.844 & $1.70 \%$ & $1.24 \%$ \\
Summer Veg. & 1.647 & 1.413 & 0.925 & $2.55 \%$ & $1.92 \%$ \\
Field Crops & 0.316 & 0.293 & 0.134 & $5.96 \%$ & $4.46 \%$ \\
Fruit Tress & 0.883 & 0.806 & 0.542 & $3.05 \%$ & $2.26 \%$ \\
Average & 1.365 & 1.179 & 0.763 & $2.54 \%$ & $1.88 \%$ \\
\hline
\end{tabular}

Summer vegetables show the highest ability to pay (JD $0.95 \mathrm{~m}^{-3}$ ). This could be due to water scarcity and banning summer cultivation in some years as a method of water rationing. The FAP for winter vegetables is JD 0.84 $\mathrm{m}^{-3}$. The percentage of water cost to total cost is $1.24 \%$. Therefore, the interviewed farmers does not consider water charges as a problem and they stress their willingness to pay higher water tariff for irrigation water in case of improvement in quality and quantity and most of farmers complain of water scarcity and not sufficient water delivery.

\subsection{Farmers' Ability to Pay by Water Quality}

The value of water quality can be looked at in several ways; poor water quality, for instance, can limit the crops a farmer is able to grow or reduces water use efficiency and yield [40]-[42]. Therefore, water quality is multidimensional, as it includes concentration of certain chemicals, level of salinity, concentration of bacteria and organic matter, as well as temperature. The Jordan Valley will divide in to four geographical locations by source of water, Northern areas irrigated with fresh water which is dominated by citrus crops, Middle areas irrigated with blended water dominated by winter vegetables, Southern Jordan Valley irrigated with blended water and side wadies in addition to brackish artisan wells. The dominant crops in these areas are winter vegetables and banana. The Southern Dead sea area (Safi area) irrigated with surface water and dominated by winter tomatoes. Surface fresh water is used in Northern Jordan Valley appears overall to be of acceptable quality and low salinity compared with other sources. The maximum farmer's ability to pay for surface water is the highest with JD $0.81 \mathrm{~m}^{-3}$ and fresh water in Safi area with JD $0.79 \mathrm{~m}^{-3}$.Treated wastewater plays a major role in narrowing the gap between supply and demand in the agricultural sector in Jordan. The effluent of As Samra WWTP is discharged to Zarqa River where it is used for restricted irrigation upstream of KTD and for unrestricted irrigation downstream of KTD after mixing with its water. Poor water quality can limit the crops a farmer is able to grow. Low water quality also reduces water use efficiency and thus may reduce yield but increase water use. The result shows that the farmers' maximum ability to pay for blended water is JD $0.75 \mathrm{~m}^{-3}$. This could be to lower yield of crops as a result of high water salinity. The farmers' maximum ability to pay for desalinated brackish water is JD $0.59 \mathrm{~m}^{-3}$. The desalinated water is mainly used to irrigate banana and other cash crops such as strawberry. Looking to the net profit to one cubic meter, it was found by Al-Karablieh [22] that the net profit is about JD $0.51 \mathrm{~m}^{-3}$ for Banana crop. However, about 50 reverses osmosis plants are operated by cash crops farmers in Southern Jordan Valley desalinate about $7.6 \mathrm{mcm}$ annually. The total brackish water abstraction was estimated with $11.8 \mathrm{mcm}$ annually. The author estimated the average desalination costs for 50 Reverse Osmosis plant (operational and annualized capital costs) of about JD 0.28 per cubic meter with a standard deviation of JD 0.13 per cubic meter. Therefore, the current practice of banana producers is economically rational by installing RO unit to irrigate banana, since water value is twice the desalination costs of one cubic meter. The estimated values of brackish water desalination of JD $0.59 \mathrm{~m}^{-3}$ represent the maximum price that farmers might be willing to pay for water under the current market conditions. Regarding groundwater, the farmers' maximum ability to pay for tube well water is JD $0.56 \mathrm{~m}^{-3}$. There is a trend of declining water tables and increasing salinity in most aquifers in JV, with resulting higher extraction costs (in terms of pumping as well as accelerated well replacement). Due to the increasing problem with water shortages experienced in Jordan Valley, the utilization of brackish water which was once not an attractive option has gained in prominence. The cost per unit of desalinated water has been dropping as advances have been made in desalination technology (Table 5). 
Table 5. Farmers' ability to pay and cost of water relative to total costs by water qualities in JV.

\begin{tabular}{cccccc}
\hline Water quality & $\begin{array}{c}\text { Water gross value } \\
\text { added }\left(\mathrm{JD} \mathrm{m}^{-3}\right)\end{array}$ & $\begin{array}{c}\text { Water net value added } \\
\left(\mathrm{JD} \mathrm{m}^{-3}\right)\end{array}$ & $\begin{array}{c}\text { Water net profitability } \\
(\mathrm{FAP})\left(\mathrm{JD} \mathrm{m}^{-3}\right)\end{array}$ & $\begin{array}{c}\text { Percent cost of water } \\
\text { to intermediate costs }\end{array}$ & $\begin{array}{c}\text { Percent cost of } \\
\text { water to total costs }\end{array}$ \\
\hline Fresh KAC & 1.355 & 1.182 & 0.812 & $2.46 \%$ & $1.76 \%$ \\
BTWW & 1.414 & 1.190 & 0.749 & $1.86 \%$ & $1.35 \%$ \\
Tube well & 1.324 & 1.150 & 0.562 & $5.53 \%$ & $4.49 \%$ \\
Fresh Surface & 1.279 & 1.156 & 0.794 & $2.18 \%$ & $1.65 \%$ \\
Desalinated & 1.069 & 0.982 & 0.591 & $26.2 \%$ & $20.8 \%$ \\
Average & 1.365 & 1.179 & 0.763 & $2.54 \%$ & $1.88 \%$ \\
\hline
\end{tabular}

\subsection{Farmers' Ability to Pay by Season}

The result shows that the farmers' maximum ability to pay for water in four season. The water demanded to cultivate crops in spring season is the highest ability to pay (JD $1.2 \mathrm{~m}^{-3}$ ), and the lowest was found for demanded in winter with about JD $0.72 \mathrm{~m}^{-3}$ as shown in (Table 6). The water demanded in summer has the highest percent of water cost to total production costs. The farmers' ability to pay for fruit trees and permanent crops is estimated with JD $0.53 \mathrm{~m}^{-3}$.

\subsection{Farmers' Ability to Pay by Production Technology}

Plastic houses can provide protection from the weather, a major production challenge faced by vegetable growers. The serious potential loss of crops due to freezes and rain or wind is a major challenge and concern for all vegetable growers in climates such as Jordan Valley. Also, plastic structures can protect the crop from wind and rain, but also can protect from insects when fitted with insect exclusion screens. Therefore, plastic houses systems could reduce the use of pesticides. Protected vegetable production in plastic houses can afford several advantages to producers. They include the ability to moderate temperature during various seasons of the year, wind protection, insect protection, and rain protection. In 2012 about 67,000 plastic houses are installed in Jordan Valley. The most plastic houses are found in MJV for winter vegetables. The result shows that the farmers' maximum ability to pay for water according to production technology used by farmers. The water demanded to cultivate crops with plastic house technology has the highest ability to pay JD $1.34 \mathrm{~m}^{-3}$, and the lowest was found for water used to cultivate in open field (JD $0.62 \mathrm{~m}^{-3}$ ) as shown in (Table 7). Due to high production cost by using protected agriculture in plastic houses, the percent cost of water to other production cost is only about $1 \%$ of the total costs.

\subsection{Farmers' Ability to Pay by Irrigation Technology}

Irrigation technologies commonly used in Jordan include furrow, drip and sprinkler. Open space, greenhouse and plastic tunnels are the most technologies used for cultivation or production. About $75 \%$ of the Jordan Valley is now drip irrigated while $24 \%$ is surface irrigated and only less than $1 \%$ is sprinklers irrigated. Additional attention must now be paid to improve the management of on-farm systems and thereby increase their efficiency. In the JRV most farmers (75\%) had a reservoir on their farms, $46 \%$ of farmers connected their drip irrigation systems directly to JVA pressure lines. About $90 \%$ of the drip irrigation systems use in-line emitters (G.R type) in 16 - 20 mm-diameter laterals; these can deliver 3 - 4 litres per hour. The result shows that the farmers' maximum ability to pay for water according to irrigation technology used by farmers. The water used in drip irrigation technology has the highest ability to pay (JD $0.84 \mathrm{~m}^{-3}$ ), and the lowest was found for water used to cultivate open field with sprinkler irrigation (JD $0.07 \mathrm{~m}^{-3}$ ) as shown in (Table 8). The open fields crops are irrigated with sprinkler irrigation are mainly wheat, barley and alfalfa. Those had the lowest value added and profitability.

\subsection{Farmers' Ability to Pay by Individual Crop in Jordan Valley}

To get insight about the maximum water ability to pay for each crop grown in Jordan Valley, the results were aggregate level for main crops for the purpose of policy recommendations. The list of the crops sorted from top 
Table 6. Farmers' ability to pay and cost of water relative to total costs by production season in JV.

\begin{tabular}{|c|c|c|c|c|c|}
\hline Production season & $\begin{array}{l}\text { Water gross value } \\
\text { added }\left(\mathrm{JD} \cdot \mathrm{m}^{-3}\right)\end{array}$ & $\begin{array}{l}\text { Water net value added } \\
\left(\mathrm{JD} \cdot \mathrm{m}^{-3}\right)\end{array}$ & $\begin{array}{l}\text { Water Net profitability } \\
\text { (FAP) }\left(\mathrm{JD} \cdot \mathrm{m}^{-3}\right)\end{array}$ & $\begin{array}{l}\text { Percent cost of water to } \\
\text { intermediate costs }\end{array}$ & $\begin{array}{l}\text { Percent cost of water } \\
\text { to total costs }\end{array}$ \\
\hline Winter & 1.435 & 1.213 & 0.724 & $1.92 \%$ & $1.44 \%$ \\
\hline Spring & 1.866 & 1.615 & 1.193 & $1.69 \%$ & $1.12 \%$ \\
\hline Summer & 1.486 & 1.302 & 0.873 & $3.55 \%$ & $2.69 \%$ \\
\hline Autumn & 1.564 & 1.302 & 0.810 & $1.63 \%$ & $1.16 \%$ \\
\hline Permanent & 0.874 & 0.798 & 0.534 & $3.12 \%$ & $2.31 \%$ \\
\hline Average & 1.365 & 1.179 & 0.763 & $2.54 \%$ & $1.88 \%$ \\
\hline
\end{tabular}

Table 7. Farmers' ability to pay and cost of water relative to total costs by production technologies in JV.

\begin{tabular}{cccccc}
\hline $\begin{array}{c}\text { Production } \\
\text { technologies }\end{array}$ & $\begin{array}{c}\text { Water gross value } \\
\text { added }\left(\mathrm{JD} \cdot \mathrm{m}^{-3}\right)\end{array}$ & $\begin{array}{c}\text { Water net value added Water net profitability } \\
\left(\mathrm{JD} \cdot \mathrm{m}^{-3}\right)\end{array}$ & $\begin{array}{c}\text { Percent cost of water to } \\
\text { (FAP) }\left(\mathrm{JD} \cdot \mathrm{m}^{-3}\right)\end{array}$ & $\begin{array}{c}\text { Percent cost of water } \\
\text { intermediate costs }\end{array}$ & $\begin{array}{c}\text { total costs } \\
\text { Open field }\end{array}$ \\
1.091 & 0.980 & 0.620 & $2.87 \%$ & $2.15 \%$ \\
Plastic houses & 2.413 & 1.948 & 1.343 & $1.46 \%$ & $1.01 \%$ \\
Plastic tunnel & 1.502 & 1.237 & 0.681 & $1.50 \%$ & $0.99 \%$ \\
Average & 1.365 & 1.179 & 0.763 & $2.54 \%$ & $1.88 \%$ \\
\hline
\end{tabular}

Table 8. Farmers' ability to pay and cost of water relative to total costs by irrigation technologies in JV.

\begin{tabular}{cccccc}
\hline $\begin{array}{c}\text { Irrigation } \\
\text { technologies }\end{array}$ & $\begin{array}{c}\text { Water gross value } \\
\text { added }\left(\mathrm{JD} \cdot \mathrm{m}^{-3}\right)\end{array}$ & $\begin{array}{c}\text { Water net value added Water net profitability } \\
\left(\mathrm{JD} \cdot \mathrm{m}^{-3}\right)\end{array}$ & $\begin{array}{c}\text { Percent cost of water to } \\
\text { ifAP) }\left(\mathrm{JD} \cdot \mathrm{m}^{-3}\right)\end{array}$ & $\begin{array}{c}\text { Percent cost of } \\
\text { water to total costs }\end{array}$ \\
\hline Drip & 1.500 & 1.291 & 0.843 & $2.36 \%$ & $1.75 \%$ \\
Sprinkler & 0.285 & 0.261 & 0.071 & $7.90 \%$ & $5.69 \%$ \\
Surface & 0.698 & 0.630 & 0.378 & $2.91 \%$ & $2.20 \%$ \\
Average & 1.365 & 1.179 & 0.763 & $2.54 \%$ & $1.88 \%$ \\
\hline
\end{tabular}

to lowest in term of farmers' ability to pay for water as shown in (Table 9). Cucumber shows the highest ability to pay (JD $2.26 \mathrm{~m}^{-3}$ ). The percentage of water cost to total cost is $1.1 \%$. Therefore, the interviewed farmers does not consider water charges as a problem and they stress their willingness to pay higher water tariff for irrigation water in case of improvement in quality and quantity and most of farmers complain of water scarcity and not sufficient water delivery. The weighted average for maximum farmers' ability to pay for irrigation water in Jordan valley estimated at for Okra (JD $1.46 \mathrm{~m}^{-3}$ ), for String beans at JD $1.37 \mathrm{~m}^{-3}$, for Green Beans at JD $1.35 \mathrm{~m}^{-3}$, for Tomatoes at JD $1.30 \mathrm{~m}^{-3}$, and for Dates at JD $1.18 \mathrm{~m}^{-3}$. The average FAP for water in Banana is about (JD $0.48 \mathrm{~m}^{-3}$ ) it ranged from JD $0.65 \mathrm{~m}^{-3}$ in the SJV to a lowest of JD $0.22 \mathrm{~m}^{-3}$ in NJV. The field crops are maize at JD $0.18 \mathrm{~m}^{-3}$, for olives at JD $0.13 \mathrm{~m}^{-3}$, for wheat JD $0.11 \mathrm{~m}^{-3}$, for alfalfa JD $0.09 \mathrm{~m}^{-3}$, and the last one is barley at JD $0.05 \mathrm{~m}^{-3}$. The water profitability in field crops is among the lowest in Jordan valley.

\section{Conclusions and Policy Recommendations}

The farmer's ability to pay for irrigation water in agriculture varies widely across crops, seasons, and production locations. Crop grown in plastic houses have the highest water profitability (JD $1.34 \mathrm{~m}^{-3}$ ), while field crops such as maize, barley, and wheat produce the lowest water profitability $\left(\mathrm{JD} 0.11 \mathrm{~m}^{-3}\right)$. Among fruits, olives show consistently low water profitability (JD $0.13 \mathrm{~m}^{-3}$ ), while citrus is the highest (JD $0.46 \mathrm{~m}^{-3}$ ). The results showed that the weighted average of farmers' ability to pay for water used in field crops is JD $0.13 \mathrm{~m}^{-3}$ and JD $0.84 \mathrm{~m}^{-3}$ for winter vegetable crops, JD $0.92 \mathrm{~m}^{-3}$ for summer vegetables, and JD $0.54 \mathrm{~m}^{-3}$ for fruit trees. The overall weighted average water net profitability of irrigation was estimated at JD $0.78 \mathrm{~m}^{-3}$. In general, the water costs 
Table 9. Farmers’ ability to pay and cost of water relative to total costs for main crop in Jv.

\begin{tabular}{|c|c|c|c|c|c|}
\hline Crop & $\begin{array}{l}\text { Water net profitability } \\
\text { (FAP) }\left(\mathrm{JD} \cdot \mathrm{m}^{-3}\right)\end{array}$ & $\begin{array}{c}\text { Percent cost of } \\
\text { water to total costs }\end{array}$ & Crop & $\begin{array}{l}\text { Water net profitability } \\
\text { (FAP) }\left(\mathrm{JD} \cdot \mathrm{m}^{-3}\right)\end{array}$ & $\begin{array}{l}\text { Percent cost of water } \\
\text { to total costs }\end{array}$ \\
\hline Cucumbers & 2.266 & $1.1 \%$ & Lemons & 0.464 & $1.73 \%$ \\
\hline Okra & 1.461 & $0.9 \%$ & Cabbages & 0.456 & $2.80 \%$ \\
\hline String beans & 1.372 & $1.5 \%$ & Lettuce & 0.447 & $1.26 \%$ \\
\hline Green Beans & 1.349 & $0.8 \%$ & Onion, dry & 0.430 & $1.56 \%$ \\
\hline Tomatoes & 1.307 & $1.2 \%$ & Pomegranates & 0.405 & $1.92 \%$ \\
\hline Dates & 1.181 & $2.1 \%$ & Clementine & 0.390 & $2.18 \%$ \\
\hline Sweet peppers & 0.878 & $1.2 \%$ & Cauliflowers & 0.379 & $2.58 \%$ \\
\hline Grapes & 0.871 & $2.0 \%$ & Pummels & 0.377 & $1.90 \%$ \\
\hline Potatoes & 0.855 & $1.0 \%$ & Jew's mallow & 0.364 & $1.85 \%$ \\
\hline Onion green & 0.799 & $1.9 \%$ & Prune & 0.357 & $2.41 \%$ \\
\hline Watermelons & 0.780 & $2.49 \%$ & Peaches & 0.326 & $2.17 \%$ \\
\hline Green onion & 0.712 & $2.76 \%$ & Eggplants & 0.323 & $1.64 \%$ \\
\hline Hot peppers & 0.645 & $1.95 \%$ & Grapefruits & 0.252 & $3.22 \%$ \\
\hline Squash & 0.644 & $1.84 \%$ & Maize & 0.181 & $3.40 \%$ \\
\hline Sweet melons & 0.574 & $2.25 \%$ & Olives & 0.130 & $4.07 \%$ \\
\hline Mandarins & 0.532 & $2.13 \%$ & Wheat & 0.115 & $5.16 \%$ \\
\hline Banana & 0.483 & $3.28 \%$ & Alfalfa & 0.093 & $4.76 \%$ \\
\hline Oranges & 0.465 & $1.91 \%$ & Barley & 0.050 & $6.62 \%$ \\
\hline
\end{tabular}

represent less than $2 \%$ of the total production costs. Furthermore, farmers' ability to pay differs by production technology; therefore, water can be priced according to production technology to enhance water saving. Farmers cultivating crops under plastic houses are able to pay higher prices for water reaching up to JD $1.34 \mathrm{~m}^{-3}$. Water profitability varies from region to region depending on the climate zones, production season, and water qualities. Water profitability in MJV has the highest profitability of about JD $0.93 \mathrm{~m}^{-3}$. NJV and Safi are about JD 0.792 $\mathrm{m}^{-3}$ and the lowest in SJV with about JD $0.62 \mathrm{~m}^{-3}$. This might be the dominance of citrus fruits in NJV, which requires higher amount of water compared with MJV where vegetables are the dominant cropping pattern. The average water profitability for surface water is the highest with JD $0.81 \mathrm{~m}^{-3}$ and groundwater is the lowest with JD $0.56 \mathrm{~m}^{-3}$, whereas it reaches about JD $0.75 \mathrm{~m}^{-3}$ for blended water. The observed values of water were in the range of those found in other studies for irrigated vegetables in Jordan. In a study conducted by Al-Karablieh [22], they found that the average value of irrigation water is JD $0.51 \mathrm{~m}^{-3}$ at the country level. Haddadin [28] reports that the value of water is JD $0.48 \mathrm{~m}^{-3}$ for vegetables under plastic houses, JD $0.35 \mathrm{~m}^{-3}$ for citrus crops and JD $0.37 \mathrm{~m}^{-3}$ for fruit trees. The study revealed a high level of variability in irrigation water values. It was shown that the differences in water values and FAP can be mainly attributed to several factors that can be relevant for policy makers and extension services: 1) the irrigation technology system, 2) the type of crop grown and 3) the water quality. Current prices charged for water are substantially below both the average value of water for producing crops and JVA's cost of service provision. Higher water prices could (a) encourage more efficient water use by farmers, (b) encourage shifts to higher value crops, (c) encourage the adoption of protected agriculture and green houses, (d) encourage private development of desalinated brackish water sources and (e) provide sufficient funds for better irrigation system maintenance and more effective operation. Water pricing policy should be revised to provide incentives for water saving technology. Differential prices can be applied to account for irrigation water quality. Expected consequences of raising water tariff would include a loss in the variety of cultivated crops and an increase in requirement for investments by farmers to adopt new water saving techniques. 
The increased requirement might also engender further negative secondary effects, since small-scale family enterprises, which constitute the majority of farms in the Jordan Valley, might not be able to cope with the increased financial demands. However, more efficient water use in response to higher prices would only occur if water is allocated and billed by volume rather than by area. Returning to a system of volumetric billing in the JVA service area would require retrofitting all connections with reliable meters and reestablishing a meterreading and billing system, a process which should be closely integrated with the newly-established WUAs. If farmers have to pay the full cost of O\&M, they need to pay at least JD 0.065 per cubic meter. The water value received by farmers is ten times higher than this suggested price of full cost recovery.

\section{References}

[1] UNDP (2013) Water Governance in the Arab Region: Managing Scarcity and Securing the Future. United Nations Development Programme, Regional Bureau for Arab States (RBAS).

[2] Karthikeyan, C. (2010) Economic and Social Value of Irrigation Water: Implications for Sustainability. Fourteenth International Water Technology Conference, Cairo, 21-23 March 2010, 823-835.

http://www.iwtc.info/2010_pdf/13-02.pdf

[3] World Bank (2013) Irrigation Water Pricing in the Jordan Valley. The World Bank, Washington DC.

[4] Salman, A., Al-Karablieh, E., Regner, H.-J., Wolff, H.-P. and Haddadin, M. (2008) Participatory Irrigation Water Management in the Jordan Valley. Water Policy, 10, 305-322. http://dx.doi.org/10.2166/wp.2007.051

[5] IRG (International Resources Group) and Al-Karablieh, E. (2012) Disaggregated Economic Value of Water in Industry and Irrigated Agriculture in Jordan. United States Agency for International Development (USAID).

[6] Chandrasekaran, K., Devarajulu, S. and Kuppannan, P. (2009) Farmers' Willingness to Pay for Irrigation Water: A Case of Tank Irrigation Systems in South India. Water, 1, 5-18. http://dx.doi.org/10.3390/w1010005

[7] Ashfaq, M., Jabeen, S. and Baig, I.A. (2005) Estimation of the Economic Value of Irrigation Water. Journal of Agriculture and Social Sciences, 1, 270-272.

[8] Gibbons, D. (1986) The Economic Value of Water. Resources for the Future, Washington DC.

[9] Young, R. (2005) Determining the Economic Value of Water: Concepts and Methods. Resource for the Future, Washington DC.

[10] Koss, P. and Khawaja, M.S. (2001) The Value of Water Supply Reliability in California: A Contingent Valuation Study. Water Policy, 3, 165-174. http://dx.doi.org/10.1016/S1366-7017(01)00005-8

[11] FAO (2000) Application of the Contingent Valuation Method in Developing Countries: A Survey. Economic and Social Development Paper 146, Food and Agriculture Organization of United Nation, Rome, 9.

[12] Salman, A. and Al-Karablieh, E. (2004) Measuring the Willingness of Farmers to Pay for Groundwater in the Highland Area of Jordan. Agricultural Water Management, 68, 61-76. http://dx.doi.org/10.1016/j.agwat.2004.02.009

[13] Venkatachalam, L. (2004) The Contingent Valuation Method: A Review. Environmental Impact Assessment Review, 24, 89-124. http://dx.doi.org/10.1016/S0195-9255(03)00138-0

[14] Venkatachalam, L. (2006) Factors Influencing Household Willingness to Pay (WTP) for Drinking Water in Peri-Urban Areas: A Case Study in the Indian Context. Water Policy, 8, 461-473. http://dx.doi.org/10.2166/wp.2006.055

[15] Turner, K., Georgiou, S., Clark, R. and Brouwer, R. (2004) Economic Value of Water Resources in Agriculture. From the Sectoral to a Functional Perspective of Natural Resource Management. FAO Water Reports 27, Rome. http://www.fao.org/docrep/007/y5582e/y5582e00.htm\#Contents

[16] Birol, E., Karousakis, E.K. and Koundouri, P. (2006) Using Economic Valuation Techniques to Inform Water Resources Management: A Survey and Critical Appraisal of Available Techniques and an Application. Science of the Total Environment, 365, 105-122. http://dx.doi.org/10.1016/j.scitotenv.2006.02.032

[17] Hussain, I., Turral, H., Molden, D. and Ahmad, M. (2007) Measuring and Enhancing the Value of Agricultural Water in Irrigated River Basins. Irrigation Science, 25, 263-282. http://dx.doi.org/10.1007/s00271-007-0061-4

[18] Abu-Zeid, M. (2001) Water Pricing in Irrigated Agriculture. International Journal of Water Resources Development, 17, 527-538. http://dx.doi.org/10.1080/07900620120094109

[19] Lange, G.M. and Hassan, R., Eds. (2007) Case Studies of Water Valuation in Namibia’s Commercial Farming Areas. The Economics of Water Management in Southern Africa: An Environmental Accounting Approach. Edward Elgar Publishing, Cheltenham.

[20] Speelman, S., Farolfi, S., Perret, L., D’haese, L. and D’haese, M. (2008) Irrigation Water Value at Small-Scale Schemes: Evidence from the North West Province, South Africa. International Journal of Water Resources Development, 24, 621-633. http://dx.doi.org/10.1080/07900620802224536 
[21] Rigby, D., Alcon, F. and Burton, M. (2010) Supply Uncertainty and the Economic Value of Irrigation Water. European Review of Agricultural Economics, 37, 97-117. http://dx.doi.org/10.1093/erae/jbq001

[22] Al-Karablieh, E., Salman, A., Al-Omari, A., Wolff, H.-P., Al-Assa'd, T., Hunaiti, D. and Subah, A. (2012) Estimation of the Economic Value of Irrigation Water in Jordan. Journal of Agricultural Science and Technology, 5, 487-497.

[23] DOS (2012) Annual Agricultural Statistics 2012. Department of Statistics, Amman.

[24] Al-Karablieh, E., Jabarin, A.S. and Tabieh, M.A. (2011) Jordanian Horticultural Export Competitiveness from Water Perspective. Journal of Agricultural Science and Technology, 1, 964-974.

[25] Al-Assaf, A., Salman, A., Fisher, F.M. and Al-Karablieh, E. (2007) A Trade-Off Analysis for the Use of Different Water Sources for Irrigation (The Case of Southern Shounah in the Jordan Valley). Water International, 32, 244-253. http://dx.doi.org/10.1080/02508060708692204

[26] MWI (2012) Annual Report 2012. Ministry of Water and Irrigation, Amman.

[27] Salman, A., AL-Karablieh, E. and Haddadin, M. (2008) Limits of Pricing Policy in Curtailing Household Water Consumption. Water Policy, 10, 295-307. http://dx.doi.org/10.2166/wp.2008.040

[28] Haddadin, M.J., Salman, A. and Al-Karablieh, E. (2006) The Role of Trade in Alleviating Water Shortage. In: Haddadin, M.J., Ed., Water Resources in Jordan (Evolving Polices for Development, the Environment and Conflict Resolution), Resources for the Future, Washington DC, 17.

[29] Wolff, H.-P., Al-Karablieh, E., Al-Assa'd, T., Subah, A. and Salman, A.Z. (2012) Jordan Water Demand Management Study: On Behalf of the Jordanian Ministry of Water and Irrigation in Cooperation with the French Development Agency (AFD). Water Science \& Technology: Water Supply, 12, 38-44. http://dx.doi.org/10.2166/ws.2011.114

[30] Hellegers, P. and Davidson, B. (2010) Determining the Disaggregated Economic Value of Irrigation Water in the Musi sub-Basin in India. Agricultural, 97, 933-938. http://dx.doi.org/10.1016/j.agwat.2010.01.026

[31] Qureshi, M.E., Ranjan, R. and Qureshi, S.E. (2010) An Empirical Assessment of the Value of Irrigation Water: The Case Study of Murrumbidgee Catchment. The Australian Journal of Agricultural and Resource Economics, 54, 99-118. http://dx.doi.org/10.1111/j.1467-8489.2009.00476.x

[32] Naeser, R. and Bennett, L.L. (1998) The Cost of Noncompliance: The Economic Value of Water in the Middle Arkansas River Valley. Natural Research Journal, 38, 445-463.

[33] Heathfield, D.F. and Wibe, S. (1987) An Introduction to Cost and Production Function. MacMillan Education Ltd., London.

[34] Chambers, R.G. (1988) Applied Production Analysis-A Dual Approach. Cambridge University Press, Cambridge.

[35] Agudelo, J.I. and Hoekstra, A.Y. (2001) Valuing Water for Agriculture: Application to the Zamvezi Basin Countries. Proceedings of the International Specialty Conference on Globalization and Water Resource Management: The Changing Value of Water, Dundee, 6-8 August 2001, 9.

[36] Agudelo, J.I. (2001) The Economic Valuation of Water: Principles and Methods. Value of Water Research Report Series 5, IHE Delft, Delft.

[37] Moore, M.R. (1999) Estimating Irrigators’ Ability to Pay for Reclamation Water. Land Economics, 75, 562-578. http://dx.doi.org/10.2307/3147066

[38] Kletke, D. (1989) Enterprise Budgets. In: Tweeten, L., Ed., Agricultural Policy Analysis Tools for Economic Development, Ohio State University, Columbus, 196-206.

[39] Powers, L., Steve, I., Tim, W., Richard, T., John, S., Brent, R., Dave, S., Terry, J. and Winston, D. (1998) Horticulture Crop Enterprise Cost and Return Estimates for 1998. University of Kentucky, Lexington.

[40] Carr, G., Potter, R.B. and Nortcliff, S. (2001) Water Reuse for Irrigation in Jordan: Perceptions of Water Quality among Farmers. Agricultural Water Management, 98, 847-854. http://dx.doi.org/10.1016/j.agwat.2010.12.011

[41] Majdalawi, M. (2003) Socioeconomic Impacts of Reuse of Water in Agriculture in Jordan Valley. Farming \& Rural Systems Economics, 51, 149-157.

[42] Bazza, M. (2003) Wastewater Recycling and Reuse in the Near East Region: Experience and Issues. Water Science and Technology: Water Supply, 3, 33-50. 